\title{
The Extractive Industries Transparency Initiative
}

\author{
New Openings for Civil Society in Myanmar
}

Adam Simpson

Myanmar's broader economy and society are dominated by agriculture, but primitive accumulation through natural resource extraction has become a fundamental driver of national economic growth. It has cemented

Myanmar's structural position as a producer and exporter of raw commodities. This has given rise to a highly rapacious, uneven and often violent mode of development, and a configuration of socio-political forces that is less amenable to genuine democratisation than to violent unrest. (Jones 2018)

Th e key challenges for the National League for Democracy (NLD) government are to both manage a long-term political transition from military to civilian rule and initiate a durable economic transformation towards a more broad-based economic growth model with the benefi ts of development spread more evenly amongst the population. In the shortto-medium term, however, natural resource extraction will remain a key source of national income and foreign exchange. A successful political and economic transition to entrenched democratic rule therefore requires a far more comprehensive and inclusive approach to natural resource governance than has previously been attempted (Bauer, Shortell and Delesgues 2016).

To ensure more equitable development the issue of resource distribution must be addressed geographically and ethnically amongst the country's various states and regions, but also within society's social and economic hierarchies. For society-wide acceptance of resource distribution policies, the decision-making processes require greater public and civil society involvement. Th e legal frameworks for implementing policies of resource extraction and use must not only be seen to be fair and 
equitable, they must be applied fairly and rigorously to improve confidence in the legal system, which has traditionally been considered ad hoc and largely existing to serve the goals of the military and its associated business interests. Indeed, while the political and economic reform process under the Thein Sein government (2011-2016) transformed many areas of government administration, the judiciary, considered representative of 'a larger political order' (Cheesman 2015: 10), is widely seen as unreformed (Crouch 2018).

While a wholesale overhaul of the court system is required, other processes of environmental and natural resource governance may act as conduits towards more inclusive policy-making and assist in overcoming historical distrust and enmity between ethnic groups, government and civil society organisations (CSOs). Within the Environmental Conservation Law 2012 and its associated rules and procedures, which took several years to develop, there are requirements for project proponents to consult with civil society, community-based organisations and project-affected people (Simpson 2015). The Environmental Impact Assessment (EIA) Procedures and National Environmental Quality (Emission) Guidelines were finally launched in January 2016 in the last days of the Thein Sein government (ADB 2016).

These requirements are, however, somewhat novel in Myanmar although EIAs have been required for foreign investments since 2012 and their efficacy will take some time to determine. The role of EIAs in promoting sustainable development will become more important over time, as skills in environmental assessment increase and the regulation expertise improves. The Ministry of Natural Resources and Environmental Conservation (MONREC), formed by the NLD government in 2016 from the former Ministry of Environmental Conservation and Forestry (MOECAF) and Ministry of Mines, chairs the National Environmental Conservation Committee (NECC), which issues EIA approvals for projects if environmental protection measures have been met. MONREC should have more influence enforcing environmental protection for mining projects now that they are within its remit (Cornish and Vivoda 2016).

Another natural resource governance tool, which I argue played a crucial role in legitimising civil society's role within natural resource governance in Myanmar, is the Extractive Industries Transparency Initiative (EITI). Legislation formalising the EITI is scheduled for early 2017 (MEITI 2016), but the first of Myanmar's EITI Reports, which determine Myanmar's progress on EITI implementation, was published in January 2016 (Moore Stephens 2015b). The second EITI Report was due by March 
2017, although an extension was granted to March 2018, with Validation against the EITI Standard now due to commence in July 2018.

Th e progress of EITI i mplementation in Myanmar has closely shadowed the economic and political reform process since 2012 - initially under President Th ein Sein and now under the NLD government - and has come to symbolise a new deliberative form of governance. While the EITI is certainly more participatory than previous state-led environmental governance policies, the scope of the original EITI was quite narrow, although it has expanded over time. At its core it is simply a tool for matching government revenues with company payments to minimise the corrupt leakage of funds. Th is limited remit is completely at o dds with the expectations of many activists and communities in Myanmar: that the EITI is a key tool for the equitable distribution of resources.

As with many other governance ventures in Myanmar, implementation of the EITI has been stymied by the shortcomings or interests of the individuals involved and a lack of capacity or resources dedicated to it. Nevertheless, in the multi-stakeholder group (MSG), which is the incountry decision-making and implementing body that drives the EITI process, the government, business interests and civil society each have equal decision-making power. In a country such as Myanmar, emerging from fi ve decades of authoritarian rule, this body has the potential to transform the traditionally antagonistic relations between government and civil society (Doyle and Simpson 2006). If it were merely a body set up and overseen by the Myanmar government it would be subject solely to the whims of individual ministers, potentially undermining its rationale and eff ectiveness. Th is would have severely restricted its activities during the military-backed Th e in S ein government. Under the EITI, h owever, the MSG and the entire process are supervised by the international EITI Board, which was chaired through most of Myanmar's accession period under Th ein Sein by former UK Development Secretary Clare Short.

For the Th ein Sein government, the EITI came to epitomise Myanmar's successful return to the international community, but it also came with the cost of potential meddling by the EITI Board, which has not baulked from downgrading a wayward country; due to concerns over a government crackdown on civil society, Azerbaijan became the fi rst country to be downgraded by the Board, from Compliant to Candidate status, in April 2015. ${ }^{1}$ Increased international oversight entailed potential risks for

1 Prior to the EITI Standard 2016 a country was defin ed as a n E ITI C andidate c ountry when it was implementing the EITI but not yet Compliant. A country was defi ned as 
the Myanmar government, but successful engagement with this process has brought international praise and exposure to international norms, which is essential for the equitable development of the country.

The NLD government, with its history of street activism and opposition to the military, has further dismantled some aspects of the authoritarian state, although it has also demonstrated its own illiberal tendencies (Simpson 2017: 201-204). It should prove more open to engagement with civil society actors - for example, Maung Tin Thit, a civil society representative on the MSG, won a seat for the NLD in the 2015 elections - but it has been somewhat aloof towards civil society since forming the government, implying that, having won a landslide election victory, the NLD is the only valid actor in the governance of the country (Fink and Simpson 2018). In addition, active support for the EITI was limited during the government's first year in office. Nonetheless, as the senior technical and policy analyst at MEITI notes, no one is criticising the government for inactivity on the EITI just yet, because the people of Myanmar feel that, for the first time, 'this is our government.'

This chapter therefore examines the role of the EITI, particularly in facilitating and legitimising civil society activism, in the ongoing political and economic transition in Myanmar. It examines how political and economic reforms mediated through an internationally supervised governance process can assist in the establishment of civil society engagement and international democratic norms at a local level. Nevertheless, it also contemplates the limitations of such a process, particularly when transparency norms are faced with structural local impediments that are driven by the benefits that accrue to the current owners and controllers of the natural resources sector.

\section{The EITI and Myanmar}

The EITI is a 'global standard to promote open and accountable management of natural resources' (EITI International Secretariat 2017). It

EITI Compliant when the EITI Board considered that it met all the EITI requirements. The new Standard changed the assessment nomenclature for implementing countries to a more nuanced four-level assessment based on a country's progress towards each requirement, including civil society participation, and their overall implementation of the EITI Standard: Satisfactory, Meaningful, Inadequate or No Progress. Implementing countries must undergo Validation at least once every three years.

2 Interview with Min Zar Ni Lin, EITI senior technical and policy analyst, MEITI, Yangon, 5 September 2016. 
emerged in the early 2000s as part of a shift in global governance towards revenue transparency, particularly in the extractive sector (Haufler 2010; Van Alstine 2014). Countries implementing the EITI disclose information on tax payments, licences, contracts and production from natural resource extraction in an annual EITI Report, which is compiled by an independent administrator, allowing civil society and community groups to track the revenue from natural resources from production to the government accounts.

Th e income received by the government is reconciled against the payments made by companies to the government. If the fi gure that the government reports is less than that of the companies, there are likely to be corrupt payments to government offi cials. Th is reconciliation the refore deals with only reported payments, so it is still possible for informal 'brown paper bag' corruption to occur, but Western companies, in particular, face increasing scrutiny and pressure by shareholders and governments over transparency and potential corrupt practices. Legislation in the United States initially from 2010 (Securities and Exchange Commission 2016) and the European Union in 2013 (European Parliament and Council of the European Union 2013) has ensured that large American and European extractive companies investing in Myanmar will be required to report their payments to the government; with Myanmar in the EITI, companies from Australia, Asia and elsewhere will be required to follow suit.

Th e EITI is, however, extremely limited as a governance tool. Indeed, it is this limitation that can make it attractive to corporations and governments. It makes no direct contribution to debates over the distribution or ownership of resources, the levels or type of environmental protection or the use of government funds resulting from resource extraction. Th ese governance concerns are largely beyond the remit of the EITI, which can be considered as having a depoliticised focus on transparency that is not unproblematic (MacLean 2014). Th roughout Myanmar, h owever, there exist infl ated expectations, regarding the determination of resource distribution and ownership, in relation to what the EITI can achieve. Th i s misunderstanding is echoed in other areas of political reform including parliamentary politics where the limitations on Aung San Suu Kyi’s ability to institute reform when in opposition were not well understood.

Expectations may have been raised by the extensive media coverage the EITI received, which occurred concurrently with the emergence of a free press in the country from 2013. While in some countries the EITI has not been widely publicised (Aaronson 2011), in Myanmar, as in Liberia (Rich and Warner 2012), it received widespread coverage, resulting in some 
parts of society viewing it as a panacea for corrupt or incompetent natural resource governance. The scope of the EITI is far narrower. Numerous studies on the EITI suggest that implementation in its earlier form had a limited effect on natural resource governance (Aaronson 2011; Kolstad and Wiig 2009; Mouan 2010; Sovacool and Andrews 2015; Sturesson and Zobel 2015; Van Alstine 2014), although there is some evidence that joining the EITI reduces corruption (David-Barrett and Okamura 2013).

While the focus remains on 'transparency', the EITI Standard was launched at the EITI Global Conference in April 2013 to improve governance aspects such as civil society participation; EITI Requirement 6 within this Standard instructed applicant governments 'to ensure that civil society is fully, independently, actively and effectively engaged' in the process (EITI International Secretariat 2013: 40). This civil society participation was further refined in the EITI Standard 2016, launched at the EITI Global Conference in Lima, Peru, in February 2016 (EITI International Secretariat 2016: 14). A protocol on 'Participation of civil society', which provides an assessment framework for the provisions related to civil society, was also included in the 2016 Standard. The main vehicle for civil society engagement is the MSG; its horizontal distribution of authority is unique in Myanmar. The EITI is therefore a compelling case study of the implementation of internationally mandated norms for civil society participation in natural resource governance in the South.

\section{Why Implement the EITI?}

The rationale behind the EITI is to ensure that government revenues from natural resource extraction are measurable and transparent, thereby reducing corruption and providing citizens with a tool to apply pressure on governments regarding budget expenditures. The need for greater transparency and better governance in Myanmar is evident in Myanmar's performance in related indicators. In Transparency International's Corruptions Perception Index 2016 Myanmar was perceived as one of the most corrupt countries in the world, ranked 136 out of 176 countries (Transparency International 2017). This result was a significant improvement on its 2010 result, the last year of direct military rule, when it was ranked second-to-last, equal with Afghanistan out of 178 countries, with only Somalia perceived as more corrupt.

Corruption in the natural resources sector - a sector that is particularly susceptible to corruption (Simpson 2018) - was even worse. The Resource Governance Index was launched by the Revenue Watch Institute, now the 
Natural Resources Governance Institute (NRGI) (2013), at the 2013 EITI and Mining for Development Conferences in Sydney. As the Myanmar minister for Mines looked on the Index was unveiled, revealing that Myanmar ranked last out of $\mathrm{fi} f \mathrm{ft}$-eight resource-rich countries in terms of the quality of governance in the extractive sector. Its composite score of 4 out of 100 was also particularly low; Equatorial Guinea, which ranked fi ft y-sixth, still managed a score that was more than three times higher. Th is assessment was undertaken before many recent reforms had come into play; with, for instance, improved transparency in the auctions for oil and gas blocks in 2014, ${ }^{3}$ Myanmar's score and ranking will no doubt improve in the next Index. Nevertheless, as the baseline report of the extractives industry prepared by Adam Smith International noted,

\begin{abstract}
Previously, many grievances with the extractive industries sector were resolved by fiat or use of force, rather than through policy-making, mediation or dialogue. We must therefore begin by acknowledging the reality that misinformation and historically derived distrust still exists. (Adam Smith International 2015: 9)
\end{abstract}

Myanmar's ethnic diversity and history of conflict and authoritarianism have resulted in incredibly complex political and economic systems with overlapping and contested de jure and de facto authority structures (Joliffe 2015). Many of Myanmar's natural resources are situated in ethnic minority areas, which has resulted in civil society opposition (Simpson 2007; 2013) and exacerbated long-term civil conflicts (see Simpson, Farrelly and Holliday 2018; South 2009); in their statistical study on forest resources and conflict Rustad et al. (2008) found that forest resources generally have a negligible influence on both conflict onset and conflict duration, but they cited Myanmar as the clearest case where it did exist. The EITI is generally supported across Myanmar's society, but there is some concern in ethnic areas that it will reinforce centralised control of natural resources in ethnic areas, as the EU's Forest Law Enforcement, Governance and Trade (FLEGT) Facility may do with forests. ${ }^{4}$

Due to conflict and corruption there is a significant black economy that is not captured when measuring the official economy. In addition, all levels of government and bureaucracy in Myanmar have extremely limited capacity and resources; although there is a concerted effort underway to digitalise the information, much of the government data remains

\footnotetext{
${ }^{3}$ Interview with Asia Pacific/Myanmar manager, NRGI, 3 February 2015, Yangon.

${ }^{4}$ Interview with Wong Aung, former co-ordinator, Shwe Gas Movement, 21 January 2015, Yangon.
} 
on paper. ${ }^{5}$ These factors have resulted in the resources sector being particularly opaque with related economic flows difficult to quantify and the resultant data unreliable. Analysis of the gemstones industry, which is dominated by jade mining and trade, has indicated just how unreliable government data can be (Irwin 2016).

Officially, all gemstones and jade produced in Myanmar must be sold at the government's annual Myanmar Gems Emporium, and the government insisted that this be the figure that was used for the EITI. In the 2015 Emporium, gemstone sales were US $\$ 1.26$ billion, down from a record US $\$ 3.4$ billion the previous year, with jade accounting for about 90 per cent of the total sales (Reuters 2015). According to Myanmar's Central Statistical Organization jade exports were approximately US $\$ 1$ billion, or 10 per cent of the total, in the financial year April 2013-March 2014, with around the same amount in 2014-2015 (Central Statistical Organization 2016a; 2016b; Moore Stephens 2015a: 15). However, according to Chinese customs data provided to the UN's Comtrade database, China imported US\$12.3 billion of gemstones from Myanmar in 2014, with most of the trade being jade (NCRA 2015). While almost all of Myanmar's jade is ultimately exported to China, ${ }^{6}$ the discrepancy between these figures indicates that there may be far more jade being mined and exported than the government admits. The Chinese figures also include only official exports; there may be significant flows of gemstones in the black economy not being accounted for in these figures.

Furthermore, an extensive report by Global Witness (2015) employed two separate estimates of the jade sector: a primary methodology based on a complex analysis of jade grades and volumes and a secondary approach employing the aforementioned Chinese data. Both methods concluded that the value of the jade mined in 2014 was worth more than US\$30 billion, which was almost half Myanmar's total estimated 2014 GDP of US $\$ 64$ billion (World Bank 2015a). Both estimates were based on official production data that took no account of the jade production kept entirely off the books, which was likely to be significant.

There is great uncertainty and unreliability in the gemstone sector data, however, with recent UN Comtrade figures from China suggesting

\footnotetext{
${ }^{5}$ As an incredulous economic specialist with the Korea International Cooperation Agency (KOICA) who was assisting with Myanmar's calculation of GDP noted: 'in the office there were large bundles of papers everywhere - these are the sources to calculate GDP'. Interview, 30 January 2014, Naypyidaw.

${ }^{6}$ Email correspondence with researcher at Global Witness, 2 March 2016.
} 
that the US $\$ 12.3$ billion in offi $\mathrm{c}$ i al ge mstone im ports fr om My anmar in 2014 was almost an order of magnitude greater than any other year. In 2013, only US $\$ 1.2$ billion was registered. In 2015 imports fell from the high in 2014 to US $\$ 2.3$ billion and in 2016 they collapsed even further to US $\$ 179$ million (United Nations 2017). As a senior researcher at Global Witness suggested, these fl u ctuations could have been d ue to the anticorruption drive in China. ${ }^{7}$ Some of the highest profi le cases involved jade, which could have resulted in more trade being declared in the short term with demand dissipating in the longer term. Without greater transparency in government data it remains extremely diffi cult to understand the nature and dynamics of the industry as a whole. Nonetheless, all the available analysis suggests that the fi gures used in the EITI for gemstones are likely to be a small fraction of what the industry actually produces, which highlights a severe limitation of the EITI process.

Even before the EITI Standard was adopted, however, the EITI Board and Secretariat made clear that transparency was only a starting point for the EITI. From the earliest moments of implementation in Myanmar, Zaw Oo, the national co-ordinator of Myanmar EITI (MEITI), which was based in the Centre for Economic and Social Development (CESD) within the Myanmar Development Resource Institute (MDRI), saw the EITI and MSG primarily as a vehicle for getting tripartite co-operation between government, business and civil society, rather than as a 'standalone process' or 'an end in itself'. ${ }^{8}$ As trust-building activities these processes could provide opportunities to not only improve environmental governance across the country but also to facilitate the evolving peace process, which is intimately tied to the equitable sharing of natural resources. ${ }^{9}$ Nevertheless, decades of authoritarian rule and disinvestment in education and institution-building in the country left government administration and trust between actors in a parlous state resulting in a challenging environment for negotiations.

\section{Joining the EITI Club}

Th e political and economic transformation that is currently taking place in Myanmar has brought Myanmar in from the cold in relation to the West

\footnotetext{
7 Email correspondence with senior researcher at Global Witness, 16 May 2017.

8 Interview with Zaw Oo, director of research and program leader, MEITI, 23 May 2013, Sydney, Australia.

9 I nterview with Aung Naing Oo, associate program director, Myanmar Peace Centre, 13 June 2013, Yangon.
} 
with foreign governments, international financial institutions and many international organisations working with the Myanmar government for the first time since the late 1980s (Simpson and Park 2013). Since 2011 aid agencies, such as Australian Aid and the UK Department for International Development (DfID), have rapidly expanded their aid programmes in Myanmar and, having bypassed the state for much of the previous two decades, now work directly with the state to provide international expertise in environmental and natural resource governance, as well as health and education. As the Western sanctions regime fell away under the Thein Sein government, the EITI became one of the key indicators of this increased engagement between Myanmar and the international community, which saw the EITI as a vehicle for both increasing civil society engagement and promoting international governance norms. In July 2012 Jonas Moberg, the head of the EITI Secretariat, visited Myanmar for the first time at the invitation of the government, which had indicated it wanted to join the EITI. Myanmar's intentions were confirmed in December of that year by Thein Sein in a Presidential Decree, and Soe Thein, minister of the President's Office, was appointed to chair the EITI Leading Authority, the executivelevel body (EITI International Secretariat 2017).

Consequently, in May 2013 Australian Aid sponsored a Myanmar delegation to Australia to attend the Global EITI and Mining for Development Conferences in Sydney and conduct field trips to Australian mines. Anticipating the membership of the EITI MSG, the delegation included civil society activists, civil servants and the ministers of Mines and Energy. Although the minister for Finance attended only briefly, the minister for Mines, Myint Aung, spent most of the trip with the group, giving activists and government officials an unprecedented opportunity for interaction and laying the groundwork for much of the collaboration to come. Most activists involved with the EITI agree that the Ministry of Mines was the most helpful of the bureaucracies with the Ministry of Finance also relatively open; the Ministry of Energy was, however, 'tougher' to engage with. ${ }^{10}$ The openness of the minister for Mines to outside influences was evident by his interest in the views of foreign academics on contract renegotiation and civil society, particularly in relation to the Shwe Gas Project. ${ }^{11}$ Although significant renegotiation of the Shwe Gas contract was unlikely, given its intense importance to China's energy

10 Interview with Asia Pacific/Myanmar manager, NRGI, 3 February 2015, Yangon; interview with Ko Ko Lwin, Myanmar associate, NRGI, 21 January 2015, Yangon.

${ }^{11}$ Interview with Myint Aung, Union minister, Ministry of Mines, Union of Myanmar, 23 May 2013, Sydney, Australia. 
security, the minister announced to parliament two months later that the contract for the Letpadaung (Letpadan/Monywa) Copper Mine had been renegotiated to provide more favourable terms for the government and local communities at the expense of China's Wanbao Mining Ltd.

Despite this hitherto unknown willingness by some parts of government to work closely with non-government actors, the attitude of much of government remained antagonistic and aloof when negotiating with civil society. It gradually became clear that although the Th in Sein gvernment had signed up to the EITI and the civil society commitments that it entailed, they were largely unprepared to actually undertake it. Th e residual militarism and authoritarianism of the government resulted in a limited acceptance of the role of civil society as designated equal partners within the MSG.

Civil society within Myanmar mostly comprises activists who opposed military rule, either within the country or in the border areas, although some activists such as Win Myo Th u of ECODEV had previous experience of working with the government. Negotiations between civil society and the government, and to some extent the MEITI team within MDRI, were therefore oft e $\mathrm{n}$ ractious, $\mathrm{w}$ ith a lack of $\mathrm{n}$ egotiating expertise on both sides, leading to regular threats to walk away from the process. ${ }^{12}$ Nevertheless, throughout 2013 civil society undertook a significant national consultation programme to determine the CSO membership of the MSG. In October 2013, 150 representatives of CSOs from all over the country met in Yangon to discuss the EITI and elect the civil society representatives for the MSG. ${ }^{13}$ Th is civil society movement eventually formalised into the Myanmar Alliance for Transparency and Accountability (MATA), which became the main umbrella CSO negotiating the EITI.

\section{The M ulti- S takeholder Group}

Th e MSG is the d riving force of the E ITI in e ach c ountry. In Myanmar under President Th e in S ein, it w as chaired by Maung Maung Th en, the deputy fi nance minister. MEITI eventually settled on nine CSO representatives, eight government representatives and six business representatives for the MSG, although each group had an equal vote in decision-making.

12 Interview with international adviser to MEITI, 27 July 2015, Yangon.

13 Interview with Ko Ko Lwin, activist with Spectrum (now Myanmar associate, NRGI), 3 February 2014, Yangon.

14 Interview with Ma Taryar, national co-ordinator, MATA, 30 January 2015, Yangon. 
Civil society had successfully argued to the international EITI Secretariat that their historical political marginalisation, together with the complexity of ethnic areas, required nine members to adequately represent the sector. To manage the MSG workload, three technical subcommittees were established: Governance, Technical, and Communication and Outreach. ${ }^{15}$

Limitations on Myanmar's governance capacity, and potentially the government's interest in the EITI, were evident throughout the MSG selection and operation period. Although the first MSG meeting was finally held in Naypyidaw on Saturday 8 February 2014 there was a sense of chaos in the MEITI office in the lead-up to the meeting as the designated dates shifted to and fro with MEITI receiving instructions from the Ministry of Finance. ${ }^{16}$ The date was finalised only on the afternoon of Tuesday 4 February. The MEITI international consultant therefore notified business representatives on Wednesday 5 February, leaving them only two business days to organise their teams, with no flights back to Yangon on Saturday afternoon. The consultant argued that setting the meeting in Naypyidaw on the weekend with such short notice and limited travel options would result in business not being seriously engaged: 'they won't send MDs [managing directors] they'll send a minion., ${ }^{17}$

Although a diverse range of ethnic minority members were elected to the MSG, Bamar (Burman) CSO representatives still dominated; the Shwe Gas Movement representative from Rakhine State joined the group only due to pressure from international EITI advisers rather than through the Yangon-dominated civil society. ${ }^{18}$ Some observers argued that two leading Bamar representatives dictated the October 2013 meeting, and tended to 'bully' other representatives. ${ }^{19}$ Although personal traits can also play a role, the 'blindness' (Walton 2013) of Bamar society to their privileged position under military rule can result in the replication

15 Interview with Min Zar Ni Lin, EITI senior technical and policy analyst, MEITI, Yangon, 5 September 2016.

16 Interview with Min Zar Ni Lin, research associate and deputy leader, MEITI, 3 February 2014, Yangon.

${ }^{17}$ Interview with international adviser to MEITI, 4 February 2014, Yangon.

18 Interview with Wong Aung, former co-ordinator, Shwe Gas Movement, 25 March 2014, Yangon.

19 Interview with head of an international organisation in Myanmar, 25 March 2014, Yangon. As Brooten and Metro note, while undertaking research in Myanmar anonymity of local subjects 'cannot always be guaranteed if the organization, the setting, or the individual may be identified even if anonymised' (2014: 12). This applies equally to Western subjects or 'internationals' based in the country who require their identity to be withheld to continue their work (Simpson 2017: 158). 
of this dominance within civil society. Some of this dominance was also refl ected in technical expertise, however; in a meeting with Clare Short in Naypyidaw in December 2013, civil society proved themselves much more organised and impressive than the government and MDRI. ${ }^{20}$ Th e issue of ethnic representation in the MSG was raised again by some foreign governments and international organisations who tried to include Muslim representation or voices in the process. Th is was particularly pertinent for the Rohingya and other Muslims who make up one-third of Rakhine State, given that the rationale of the MSG was to give voice to marginalised sectors of society. In response to such suggestions the second Rakhine representative announced: 'if you include Kala [a derogatory term for Rohingya], I'll walk out'. ${ }^{21}$

Myanmar's EITI candidature application was eventually submitted on 7 May 2014 (MEITI 2014), and at the EITI Board Meeting in Mexico City on 2 July 2014 Myanmar was formally accepted as a Candidate country. MEITI then had eighteen months to produce the fi rst EITI Report, due on 2 January 2016, which fell during the Th ein Sein government's caretaker period after the NLD's election win. Th e Mi nistry of Finance, now the Ministry of Finance and Planning, created a secretariat to assume MEITI responsibilities aft er publication of the fi rst report, but six months before the handover it still had no staff working on the EITI full time. ${ }^{22}$

Despite the limited remit of the EITI, CSOs endeavoured to broaden the role of the MSG to deal with any related natural resource governance issues. Th is became evident in January 2015 when CSOs called an emergency MSG meeting in January 2015 over the shooting of a protester at the Letpadaung Copper Mine in December 2014 (Fortify Rights and International Human Rights Clinic 2015). ${ }^{23}$ Following the aforementioned contract renegotiation in mid-2013, Wanbao Mining became a minority stakeholder in the mine, holding 30 per cent, with its business partner, the military-backed Union of Myanmar Economic Holdings Ltd (UMEHL), holding 19 per cent; the Myanmar government (No.1 Myanmar Enterprise) took a 51 per cent share. Due to disagreements over the shooting and its relevance to the EITI MSG both the government and civil society threatened to withdraw from the entire EITI process,

20 Interview with International Adviser to MEITI, 21 January 2015, Yangon.

21 Interview with Min Zar Ni Lin, Research Associate and Deputy Leader, MEITI, 3 February 2015, Yangon; Interview with International Adviser to MEITI, 21 January 2015, Yangon.

22 Interview with international adviser to MEITI, 27 July 2015, Yangon.

23 Interview with Ko Ko Lwin, Myanmar associate, NRGI, 21 January 2015, Yangon. 
although the CSOs were split with 'personalities' causing ruptures in the decision-making processes. ${ }^{24}$ The head of the EITI Secretariat, Jonas Moberg, flew in to try and placate both sides. ${ }^{25}$

CSOs were attempting to deploy the EITI as a human rights grievance mechanism, which the MEITI international consultant argued reflected a 'lack of understanding' of what the EITI was for. ${ }^{26} \mathrm{An}$ alternative interpretation of the action is that the EITI was one of the few channels where government was forced to sit down with CSOs and listen to their grievances. It is therefore unsurprising that CSOs would leverage their internationally mandated influence by attempting to expand the issues to be dealt with by the EITI and MSG. As a consequence of the dispute, the international consultant offered to meet with Wanbao to discuss issues related to the EITI and the mine. The response was an email in which Wanbao argued that they were only a minority shareholder and they would be bound by the EITI, so there was no need to meet; they added 'we wish you well with your little project. ${ }^{27}$

To decentralise management of the EITI the MSG agreed in October 2014 to establish four pilot 'MEITI subnational coordination units', in Mandalay Region, Magway Region, Shan State and Rakhine State. The aim of these units was to provide a 'local-level platform for dialogue on local issues of concern relating to the extractive industries' (MEITI 2015: 5). There was no local-level reporting process, but each unit was to develop their own work plans with activities that focused on public consultation. By late 2016, however, only Magway had established an MSG, although some progress had also been made in Mandalay. ${ }^{28}$

Nevertheless, the inclusion of Rakhine State as a sub-national unit caused some consternation amongst the international advisers, given the communal conflict in the state and the general Rakhine aversion to the inclusion of Muslim or Rohingya voices in the process. The World Bank was pushing to include Rohingya in the process through MATA, but its national co-ordinator, Ma Taryar, argued that the CSO did not work that way: 'if they have a natural resource governance CSO then that is fine but so far

24 Interview with Wong Aung, former co-ordinator, Shwe Gas Movement, 21 January 2015, Yangon.

25 Interview with Min Zar Ni Lin, research associate and deputy leader, MEITI, 3 February 2015, Yangon.

26 Interview with international adviser to MEITI, 21 January 2015, Yangon.

27 Interview with international adviser to MEITI, 27 July 2015, Yangon.

28 Interview with Min Zar Ni Lin, EITI senior technical and policy analyst, MEITI, Yangon, 5 September 2016. 
we haven't seen one. ${ }^{29}$ Given the restrictions placed on the movement and activities of the Rohingya community, with more than 100,000 still in internment camps, it could be argued that greater civil society outreach could be undertaken for this community in Rakhine State.

\section{Improving Resource Governance through the EITI Report}

Th e annual EITI Report contains the reconciliation data and determines a country's progress on EITI implementation. It is therefore the main document available to civil society to pursue improved resource governance goals. Th e s ectors a ssessed in Myanmar's fi rs t EI TI Re port, re leased in January 2016 (Moore Stephens 2015b), were set out in the Scoping Report prepared by the consultancy Moore Stephens, which was fi nalised 12 November 2015 (Moore Stephens 2015a). Th e ir fi rst contract was to prepare a Scoping Report and prepare a five-year reporting roadmap. Prior to their arrival in Myanmar in mid-2015 they sent numerous requests to MEITI to set up meetings. When they arrived, however, no meetings had been organised, signifi cantly d elaying the r eport. ${ }^{30}$ Th e se cond contract was to produce the fi nal EITI Report on the reconciliation between the company and government fi gures for the fi nancial year April 2013-March 2014 (Moore Stephens 2015b). ${ }^{31}$

Th e o nly s ectors t o b e i ncluded in the r econciliation w ere o il a nd gas (including transportation), which was relatively simple due to the involvement of international business and large contracts, and mining (including gems and jade), which, with its diverse scales, multitude of stakeholders and deep integration with the economies of the ethnic minority-controlled areas, presented a more complex array of challenges. Th e government initially a rgued that gems and jade should be excluded from the EITI process, ${ }^{32}$ but the benefits of an internationally supervised process meant that the international consultant, backed by the EITI Secretariat and Board, ensured that these core sectors were included.

Although some CSOs wanted to include hydroelectricity, it was agreed that it would be left out of the reconciliation in the fi rst report but that a schedule would be incorporated into the report to include it at a later date.

\footnotetext{
29 Interview with Ma Taryar, national co-ordinator, MATA, 30 January 2015, Yangon.

30 Interview with international adviser to MEITI, 27 July 2015, Yangon.

31 Email correspondence with international adviser to MEITI, 19 November 2015.

32 Interview with international adviser to MEITI, 21 January 2015, Yangon.
} 
The EITI has not traditionally encompassed hydroelectricity, but it has begun to be included by some countries, such as Albania. In Myanmar, the prospect of numerous large dams in ethnic areas on the Thanlwin (Salween) and Ayeyarwady (Irrawaddy) Rivers made this a priority for some ethnic CSOs (Kirchherr, Charles and Walton 2016; Simpson 2013). Other CSOs wanted either forestry or fisheries included; forestry was excluded because the FLEGT process has set up a parallel internationally mediated governance regime, and fisheries was considered non-core for the initial EITI Report. Moore Stephens's Scoping Report recommended hydropower and fisheries be included in future EITI Reports (Moore Stephens 2015a: 7).

The reconciliation was difficult because not only are most of the government records kept on paper, there are also no records of disaggregated tax revenue by company. The reconciliation was therefore based on nontax data such as royalties, customs and production. As difficult as this task was, government intransigence, particularly from the Ministry of Energy, made the task even more difficult. Some of the limitations to the Scoping Report were set out by Moore Stephens:

(i) The conclusions of our work have been based partially on data and information provided by government entities which have not been previously audited or reconciled ...

(ii) We did not obtain the statement of revenues collected from the extractive sector from the IRD and Custom Department.

(iii) We did not obtain the desegregated data (by licensee) on revenue streams collected from small operators from the MoM [Ministry of Mines], except for emporium data for Jade and Gemstone.

(iv) We did not obtain the comprehensive list of Military Holding companies and their related subsidiaries.

(v) We did not obtain the list of operators in the Gems and Jade sectors from the MoM (Moore Stephens 2015a: 6).

Each of these limitations is a key issue, but it is clearly difficult to undertake a thorough reconciliation of the extractive sector without taking into account tax data from the Internal Revenue Department. Similarly, like many other sectors of the economy, the mining industry in Myanmar is dominated by opaque military-owned corporations - including the enormous holding companies UMEHL and Myanmar Economic Corporation (MEC) - and their associated 'cronies' who have created oligopolistic wealth (Ford, Gillan and Thein 2016; Irwin 2016; Moore Stephens 2015b: 48-49). As Moore Stephens note, they did not even receive a list 
of these holding companies, nor of their subsidiaries, so their assets and activities are clearly shielded from view. Until these corporations are forced to reveal their activities the EITI Reports will be necessarily lacking. In addition, military cronies have bankrolled peace negotiations in the past between the military and ethnic armed groups, such as the KNU and Kachin Independence Organisation, illustrating the importance to corporate interests of access to ethnic states for natural resource extraction( Jones 2014).

Th e $\mathrm{l}$ ack of $\mathrm{d}$ isaggregated c ompany $\mathrm{d}$ ata, a nd o ther a ssociated $\mathrm{d}$ ata limitations, also means that it has been diffi cult to assess the government revenue from a particular company or mine. To take one example, civil society activists want to investigate government receipts and other governance issues related to the Letpadaung Mine. ${ }^{33}$ Th e Scoping Report was woefully out of date on this issue; it failed to mention Wanbao and instead listed the Myanmar Ivanhoe Copper Company Ltd, owned by Canada's Ivanhoe, as the major foreign company with a 50:50 joint venture with No.1 Mining Enterprise. Ivanhoe's interest in the mine was taken over by Wanbao in 2011. In addition, the contract was renegotiated in July 2013, early in the year of reconciliation, but the 19 per cent interest of the military-backed UMEHL is not mentioned (Moore Stephens 2015a: 28). Letpadaung is the most high-profi le mine in the country, so the erroneous information in the Scoping Report was not encouraging, although it was corrected in the fi nal report (Moore Stephens 2015b).

When the fi nal report on fi scal year 2013-2014 was released in January 2016 much of the material had been $\mathrm{fl}$ agged in the $\mathrm{d}$ raft and Scoping Reports; the reconciliation covered three sub-sectors - oil and gas, gems and jade, and other minerals - and total Union government revenue collected from the extractive sector amounted to MMK3,011 billion (Myanmar kyat) (approximately US\$3.1 billion). Th e oil and gas sector generated the most revenue with the government collecting MMK2,569 billion (US\$2.7 billion) representing 85 per cent of total revenues. In the minerals sector the government collected MMK388 billion from gems and jade and MMK54 billion from other minerals in 2013-2014: a total of MMK442 billion (US $\$ 460$ million) which represented 15 per cent of revenues (Moore Stephens 2015b: 8-9). While not insubstantial, the gems and jade revenues represent a very small fraction of the value of the jade sector, which is more than US $\$ 30$ billion, as estimated by Global

33 Interview with Ma Taryar, national co-ordinator, MATA, 30 January 2015, Yangon. 
Witness (Global Witness 2015). The report indicates that the extractives sector comprised 6 per cent of Myanmar's GDP, 23.6 per cent of state revenues and 38.5 per cent of total exports (Moore Stephens 2015b: 10), but these statistics employ the government's figures relating to the size of Myanmar's GDP, which likely significantly undervalue the size of the jade industry.

Most of the state revenues were collected by state-owned enterprises (SOEs), ${ }^{34}$ which raised MMK2,554 billion (US $\$ 2.7$ billion) representing 85 per cent of the total. During reporting for the EITI, information on the operations and accounts of SOEs was made publicly available in Myanmar for the first time. A governance shortcoming that was highlighted in the report was the use of 'other accounts' by SOEs. From 2012-2013 government reforms allowed 55 per cent of revenues to be withheld by SOEs in these accounts, which are not counted in the state budget and can be used for their own purposes with only limited government oversight (Heller and Delesgues 2016: 28-31). In 2013-2014 SOE transfers amounted to MMK2,676 billion of which MMK1,543 billion, representing 58 per cent, was held in the 'other accounts', while the other 42 per cent was transferred to the state's budget. For instance, Myanmar Oil and Gas Enterprise (MOGE), the SOE that foreign companies must partner with in oil and gas investments, moved approximately MMK1,320 billion (US $\$ 1.4$ billion) into these off-budget accounts in 2013-2014 (Moore Stephens 2015b: 8-10), more than Myanmar spent on either health (MMK528 billion) or education (MMK909 billion) in the same period (Open Myanmar Initiative 2016; see also World Bank 2015b).

A key point Moore Stephens also highlighted in the final report was the lack of legal support for the EITI. They noted that 'the EITI reporting obligations are not covered by any other Law organising the process of collection in the current Legislation', and they recommended developing a legal framework including an EITI law that could be harmonised with existing legislation with provisions relating to:

reporting obligations for extractive companies and government entities alike, while specifying the level of disaggregation of the data to be submitted; and a time schedule for updating and publishing forms and instructions and selection of the reporting entities and submission of declarations and completion of all reconciliation work. (Moore Stephens 2015b: 79-80)

${ }^{34}$ SOEs are sometimes referred to as state-owned economic enterprises (SEEs) in Myanmar (see Heller and Delesgues 2016), but here I have used the standard international acronym. 
Th e se r equirements, w hich w ere s upported b y N GOs s uch a s G lobal Witness, ${ }^{35}$ would improve the legal standing of the EITI in Myanmar and underpin its integration into the country's broader natural resource governance framework. MATA also supported an overarching EITI law, ${ }^{36}$ while the manager of the Extractives Programme in the Myanmar Centre for Responsible Business indicated that Union-level legislation would provide more support for both CSO and MEITI representatives at township level. ${ }^{37} \mathrm{He}$ indicated that many of the CSO representatives from the MSG were not from NGOs registered with the government; they therefore receive curt treatment from township-level authorities, most of which have lived their entire lives within an authoritarian military structure that precluded civil society engagement. In contrast, the Myanmar manager of NRGI, an organisation with extensive multi-country experience on the EITI, argued that an EITI law was not necessary for successful implementation of the EITI. ${ }^{38}$ Regardless of the law's necessity, however, MEITI planned to develop legislation to support the EITI with lawmakers in early 2017 (MEITI 2016).

\section{Conclusion}

Myanmar's journey in joining the EITI has shone a spotlight on the limitations of existing natural resource governance in the country. Many of these constraints were to be expected in a country with such an authoritarian history, but signifi cant p rogress has been made in i mproving its complex political and economic systems. Eff ective reform of the extractive industries' legal and governance frameworks is an enormous challenge, but one that refl ects the broader diffi culty of encouraging equitable and sustainable development in a highly unequal and poverty-stricken country.

For the foreseeable future, it will be NLD-led governments that are tasked with navigating Myanmar through its ongoing EITI commitments and other natural resource governance reforms. Th e government took its fi rst tentative step in reforming the gemstone sector in July 2016 when it announced it would not renew mining permits for gems and jade when they expired and

\footnotetext{
35 Email correspondence with researcher at Global Witness, 2 March 2016.

36 Interview with co-ordinator, MATA, Yangon, 30 January 2015.

37 I nterview with manager, Extractives Programme, Myanmar Centre for Responsible Business, Yangon, 7 September 2016.

38 Interview with Asia Pacifi $d$ Myanmar manager, NRGI, 6 September 2016, Yangon.
} 
would not issue new permits until the by-laws associated with the amended Myanmar Gemstones Law had been passed (Ye Mon and Kyi Kyi Sway 2017). In an echo of the EITI MSG, a new trilateral committee, comprising government, industry and civil society representatives, is being established to advise on the development of a new jade policy, although some of the proposed legislative changes are superficial and would do little more than maintain the status quo (Paul Shortell 2017). ${ }^{39}$

Progress on the EITI itself was limited during the government's first year in power. The MSG associated with the Thein Sein government was disbanded, as was the EITI Leading Authority and all other government committees as the NLD sought to break with the past and stamp its authority on the new government. Unfortunately, the centralised decision-making processes of the NLD and the new government, with all significant decisions flowing through the office of Aung San Suu Kyi, meant that reconstituting these committees was a slow process. In addition, in her first year Suu Kyi appeared to focus almost exclusively on the peace process, assuming that once a comprehensive agreement was reached, other areas such as the economy could be prioritised. In reality, economic concerns, and natural resource governance in particular, are intimately interwoven with issues of ethnic and civil conflict in Myanmar. Improved natural resource governance, through greater transparency, effective environmental assessment and resource redistribution (Bauer et al. 2016), is likely to facilitate the peace process rather than flow from it.With the MSG in abeyance throughout 2016, the three technical subcommittees continued meeting to maintain some momentum, ${ }^{40}$ but funding difficulties and a lack of commitment or apparent interest from the new government meant that there were difficulties in finalising the second EITI Report, then due in March 2017. ${ }^{41}$ The NLD government eventually appointed a new EITI Leading Committee in December 2016 and applied for an extension to the EITI International Board on 31 January 2017, the last possible day. In April 2017 the Board acquiesced to their request and they were granted twelve month extensions: the second EITI Report became due on 31 March 2018 with Validation commencing 1 July 2018 (EITI International Secretariat 2017). Despite the extension, progress on the issues highlighted in the first report is likely to be limited;

39 Email correspondence with senior campaigner, Global Witness, 16 May 2017.

40 Email correspondence with regional director, EITI International Secretariat, 22 December 2016.

${ }^{41}$ Interview with Min Zar Ni Lin, EITI senior technical and policy analyst, MEITI, Yangon, 5 September 2016. 
priorities for the government to address included establishing greater parliamentary oversight of SOEs, applying transparency requirements to military-owned companies and, as a result, improving documentation of benefi cial ownership.

Th e se issues a ll point to a n u nderlyingd iffi culty for the NLD government: the structural power of the military within Myanmar's political economy and its formal authority under the military-written 2008 Constitution. The $\mathrm{m}$ ilitary $\mathrm{c}$ ontrol of $\mathrm{t}$ he $\mathrm{m}$ inistries a ssociated $\mathrm{w}$ ith defence, interior and border aff a irs, in addition to o ther constitutional powers, meant that the NLD was extremely limited in its ability to manage the ethnic minority border areas, where most confl ict occurs and natural resources are found.

Nevertheless, strong leadership from the government on the EITI, whether legislative or administrative, would promote the values of transparency and accountability in government that it espoused in opposition, providing it with moral authority to pursue recalcitrant businesses or sectors. Continuing with the EITI, which is widely considered to be a Th ein Sein initiative, and giving credit to his government for what it achieved in this area, would earn it plaudits, and possibly greater co-operation, from the military and its associated businesses. Support for the EITI would create a culture of disclosure that spreads to other parts of the natural resources sector, and eventually to other parts of government and society as well.

A potential danger for civil society actors participating in the EITI is that its administrative requirements and focus on transparency consume scarce resources, preventing them from addressing other governance issues, such as human rights or environmental degradation. From the evidence of the process so far, however, CSOs have managed to both participate in the EITI and continue with work in other areas; their attempts, which were oft en successful, to broaden the agenda of the MSG demonstrated their power, with international support, in pursuing broader goals within the EITI process itself.

In a sense the EITI is an iterative process. Myanmar's fi rst EITI Report was full of omissions and inaccuracies, but by documenting and highlighting these errors subsequent reports should improve the accuracy of reporting. As these reports are published it is the role of civil society and other stakeholders to analyse the information and use it to advocate for more broad-based and equitable development strategies than the ones that have hitherto been adopted. Given Myanmar governments' historical lack of consultation with civil society, the EITI and its international 
oversight played a crucial role in establishing civil society as a legitimate actor within natural resource governance in the country. As EIAs and public consultation become the norm within Myanmar's environmental governance system it should not be forgotten how paradigm-shattering the initial negotiations associated with the EITI were.

\section{References}

Aaronson, S. A. 2011. 'Limited Partnership: Business, Government, Civil Society, And The Public in the Extractive Industries Transparency Initiative (EITI)' 31(1) Public Administration and Development 50-63.

Adam Smith International. 2015. Institutional and Regulatory Assessment of the Extractive Industries in Myanmar. London: Adam Smith International and MDRI-CESD. Available at http://documents.worldbank.org/curated/en/ docsearch/report/96445 (accessed 1 September 2015).

Asian Development Bank (ADB). 2016. Launch Ceremony: EIA Procedures and Environmental Quality Guidelines. Bangkok: Asian Development Bank, Greater Mekong Subregion, Core Environment Program. Available at http://www.gms-eoc.org/events/launch-ceremony-eia-procedure-andenvironmental-quality-guidelines (accessed 10 October 2016).

Bauer, A., P. Shortell and L. Delesgues. 2016. Sharing the Wealth: A Roadmap for Distributing Myanmar's Natural Resource Revenues. New York: Natural Resource Governance Institute (NRGI). Available at http://www .resourcegovernance.org/sites/default/files/nrgi_sharing_Myanmar_ Revenue-Sharing.pdf (accessed 18 February 2016).

Brooten, L. and R. Metro. 2014. 'Thinking about Ethics in Burma Research'. 18(1) Journal of Burma Studies 1-22.

Central Statistical Organization. 2016a. Central Statistical Organization. Naypyitaw: Ministry of Planning and Finance. Available at http://www .csostat.gov.mm/ (accessed 21 June 2016).

2016b. Myanmar Statistical Information Service (MMSIS). Available at http:// www.mmsis.gov.mm/ (accessed 22 December 2016).

Cheesman, N. 2015. Opposing the Rule of Law: How Myanmar's Courts Make Law and Order. Cambridge: Cambridge University Press.

Cornish, G. and V. Vivoda. 2016. 'Myanmar's Extractive Industries: An Institutional and Regulatory Assessment'. 3(4) Extractive Industries and Society 1,075-1,083.

Crouch, M. 2018. 'Judiciary' in A. Simpson, N. Farrelly and I. Holliday (eds), Routledge Handbook of Contemporary Myanmar. London and New York: Routledge.

David-Barrett, L. and K. Okamura. 2013. The Transparency Paradox: Why do Corrupt Countries Join EITI? Berlin: European Research Centre for Anti-Corruption 
and State-Building. Available at http://www.againstcorruption.eu/ (accessed 20 November 2015).

Doyle, T. and A. Simpson. 2006. 'Traversing More than Speed Bumps: Green Politics under Authoritarian Regimes in Burma and Iran'. 15(5) Environmental Politics. November 750-767.

EITI International Secretariat. 2013. The EITI Standard. Oslo: Extractive Industries Transparency Initiative (EITI) International Secretariat. Available at http://eiti.org/files/English_EITI STANDARD_11July_0.pdf (accessed 10 November 2015).

2016. The EITI Standard 2016. Oslo: Extractive Industries Transparency Initiative (EITI) International Secretariat. Available at https://eiti.org/files/english_eiti_ standard_0.pdf (accessed 15 March 2016).

2017. Extractive Industries Transparency Initiative. Oslo: Extractive Industries Transparency Initiative (EITI). Available at http://eiti.org (accessed 1 June 2017).

European Parliament and Council of the European Union. 2013. EU Accounting (and Transparency) Directives (Country by Country Reporting): New Disclosure Requirements for the Extractive Industry and Loggers of Primary Forests (Directive 2013/34/EU). Strasbourg: European Union. Available at http://eur-lex.europa.eu/legal-content/EN/TXT/PDF/?uri= CELEX:32013L0034\&from=EN (accessed 1 December 2016).

Fink, C. and A. Simpson. 2018. 'Civil Society' in A. Simpson, N. Farrelly and I. Holliday (eds), Routledge Handbook of Contemporary Myanmar. London and New York: Routledge.

Ford, M., M. Gillan and H. H. Thein. 2016. 'From Cronyism to Oligarchy? Privatisation and Business Elites in Myanmar'. 46(1) Journal of Contemporary Asia 18-41.

Fortify Rights and International Human Rights Clinic. 2015. Crackdown at Letpadan: Excessive Use of Force and Violations of the Rights to Freedom of Peaceful Assembly and Expression in Letpadan, Bago Region, Myanmar. Bangkok: Fortify Rights and Harvard Law School International Human Rights Clinic. Available at http://www.fortifyrights.org/ downloads/FR_Crackdown_At_Letpadan_October_2015.pdf (accessed 11 October 2015).

Global Witness. 2015. Jade: Myanmar's 'Big State Secret'. London: Global Witness. Available at https://www.globalwitness.org/reports/myanmarjade/ (accessed 23 October 2015).

Haufler, V. 2010. 'Disclosure as Governance: The Extractive Industries Transparency Initiative and Resource Management in the Developing World'. August, 10(3) Global Environmental Politics 53-73.

Heller, P. R. P. and L. Delesgues. 2016. Gilded Gatekeepers: Myanmar's State-Owned Oil, Gas and Mining Enterprises. New York: Natural Resource Governance 
Institute (NRGI). Available at http://www.resourcegovernance.org/sites/ default/files/nrgi_Myanmar-State-Owned-Enterprises_Full-Report.pdf (accessed 18 February 2016).

Irwin, E. 2016. Gemstone Sector Review (Summary Version): In support of Myanmar EITI. Yangon: Myanmar Extractive Industries Transparency Initiative (MEITI).

Joliffe, K. 2015. Ethnic Armed Conflict and Territorial Administration in Myanmar. Yangon: Asia Foundation. Available at http://asiafoundation.org/resources/ pdfs/ConflictTerritorialAdministrationfullreportENG.pdf (accessed 15 November 2015).

Jones, L. 2014. 'The Political Economy of Myanmar's Transition'. 44(1) Journal of Contemporary Asia 144-170.

2018. 'Political Economy' in A. Simpson, N. Farrelly and I. Holliday (eds), Routledge Handbook of Contemporary Myanmar. London and New York: Routledge.

Kirchherr, J., K. J. Charles and M. J. Walton. 2016. 'The Interplay of Activists and Dam Developers: The Case of Myanmar's Mega-Dams'. 33(1) International Journal of Water Resources Development 111-131.

Kolstad, I. and A. Wiig. 2009. 'Is Transparency the Key to Reducing Corruption in Resource-Rich Countries?' 37(3) World Development 521-532.

MacLean, K. 2014. 'Counter-Accounting with Invisible Data: The Struggle for Transparency in Myanmar's Energy Sector'. 37(1) PoLAR: Political and Legal Anthropology Review 10-28.

MEITI. 2014. MEITI Candidacy Application Form. Naypyitaw: Myanmar Extractive Industries Transparency Initiative (MEITI). Available at http://eiti.org/files/ MEITI-application.pdf (accessed 9 June 2014).

2015. Myanmar EITI Annual Activity Report: July 2014-June 2015. Yangon: Myanmar Extractive Industries Transparency Initiative.

2016. Myanmar EITI Annual Activity Report: July 2015-June 2016. Yangon: Myanmar Extractive Industries Transparency Initiative.

Moore Stephens. 2015a. Myanmar Extractive Industries Transparency Initiative: Scoping Study for the First EITI Report - For the Period April 2013March 2014. London: Moore Stephens.

2015b. Myanmar Extractive Industries Transparency Initiative: EITI Report for the Period April 2013-March 2014 - Oil Gas and Mining Sectors. London: Moore Stephens.

Mouan, L. C. 2010. 'Exploring the Potential Benefits of Asian Participation in the Extractive Industries Transparency Initiative: The Case of China.' 19(6) Business Strategy and the Environment 367-376.

Natural Resource Governance Institute. 2013. The 2013 Resource Governance Index: A Measure of Transparency and Accountability in the Oil, Gas and Mining Sector. New York: Natural Resource Governance Institute (formerly 
Revenue Watch Institute). Available at https://resourcegovernance.org/sites/ default/files/rgi_2013_Eng.pdf (accessed 1 June 2017).

NCRA. 2015. A \$12bn Jade and Gem Industry Rides to the Kyat's Rescue. Yangon: New Crossroads Asia. Available at http://www.newcrossroadsasia.com/ (accessed 10 November 2015).

Open Myanmar Initiative. 2016. OMI Budget Explorer. Available at http://budget .omimyanmar.org/ (accessed 24 December 2016).

Reuters. 2015. 'Myanmar Gems Sales Slump as Conflict Stems Jade Supply'. 9 July. Available at http://www.reuters.com/article/2015/07/09/myanmar-jade-idU SL3N0ZP2DH20150709 (accessed10 November 2015).

Rich, E. and T. N. Warner. 2012. 'Addressing the Roots of Liberia's Conflict through the Extractive Industries Transparency Initiative' in P. Lujala and S.

A. Rustad (eds), High-Value Natural Resources and Peacebuilding. London: Earthscan.

Rustad, S. C. A., J. K. Rød, W. Larsen and N. P. Gleditsch. 2008. 'Foliage and Fighting: Forest Resources and the Onset, Duration, and Location of Civil War'. 27 Political Geography 761-782.

Securities and Exchange Commission. 2016. Disclosure of Payments by Resource Extraction Issuers, Final Rule, 17 CFR Parts 240 and 249b, Release No. 3478167; File No. S7-25-15, RIN 3235-AL53. Washington DC: US Securities and Exchange Commission.

Shortell, P. 2017 'Does Myanmar Need a Gemstone Law?'. Myanmar Times. 25 January. Available at http://www.mmtimes.com/index.php/opinion/24686does-myanmar-need-a-gemstone-law.html (accessed 2 June 2017).

Simpson, A. 2007. 'The Environment-Energy Security Nexus: Critical Analysis of an Energy 'Love Triangle' in Southeast Asia'. April, 28(3) Third World Quarterly 539-554.

2013. 'Challenging Hydropower Development in Myanmar (Burma): CrossBorder Activism under a Regime in Transition'. 26(2) The Pacific Review 129-152.

2015. 'Starting from Year Zero: Environmental Governance in Myanmar' in S. Mukherjee and D. Chakraborty (eds), Environmental Challenges and Governance: Diverse Perspectives from Asia. London and New York: Routledge.

2017. Energy, Governance and Security in Thailand and Myanmar (Burma): A Critical Approach to Environmental Politics in the South. Updated edition. Copenhagen: NIAS Press.

2018. 'Corruption, Investment and Natural Resources' in S. Alam, J. Bhuiyan and J. Razzaque (eds), International Natural Resources Law, Investment and Sustainability. London and New York: Routledge.

Simpson, A., N. Farrelly and I. Holliday (eds). 2018. Routledge Handbook of Contemporary Myanmar. London and New York: Routledge. 
Simpson, A. and S. Park. 2013. 'The Asian Development Bank as a Global Risk Regulator in Myanmar'. 34(10) Third World Quarterly 1858-1871.

South, A. 2009. Ethnic Politics in Burma: States of Conflict. London and New York: Routledge.

Sovacool, B. and N. Andrews. 2015. 'Does transparency Matter? Evaluating the Governance Impacts of the Extractive Industries Transparency Initiative (EITI) in Azerbaijan and Liberia'. September, 45 Resources Policy 183-192.

Sturesson, A. and T. Zobel. 2015. 'The Extractive Industries Transparency Initiative (EITI) in Uganda: Who Will Take the Lead When the Government Falters?' January, 2(1) The Extractive Industries and Society 33-45.

Transparency International. 2017. Corruption Perceptions Index 2016. Berlin: Transparency International. Available at https:/www.transparency.org/news/ feature/corruption_perceptions_index_2016 (accessed 1 June 2017).

Van Alstine, J. 2014. 'Transparency in Resource Governance: The Pitfalls and Potential of "New Oil” in Sub-Saharan Africa'. 14(1) Global Environmental Politics 20-39.

United Nations (2017) UN Comtrade Database. Available at https://comtrade .un.org/data/. (accessed 2 June 2017).

Walton, M. J. 2013. 'The "Wages of Burmanness": Ethnicity and Burman Privilege in Contemporary Myanmar'. 43(1) Journal of Contemporary Asia 1-27.

World Bank. 2015a. Myanmar. Washington DC: World Bank. Available at http:// www.worldbank.org/en/country/myanmar (accessed 10 January 2016).

2015b. Myanmar: Public Expenditure Review. Washington DC: The World Bank. Available at http://documents.worldbank.org/curated/en/5041214 67987907393/pdf/103993-WP-P132668-PUBLIC-Myanmar-PER-Dec-2015. pdf (accessed 1 December 2016).

Ye Mon and Kyi Kyi Sway. 2016. 'Jade Mining Permit Extensions Suspended'. Myanmar Times. 27 July. Available at http://www.mmtimes.com/index.php/ business/21593-jade-mining-permit-extensions-suspended.html (accessed 2 February 2017). 